\title{
EFFECT OF GAMAA RADIATION ON CHEMICAL, PHYSICAL AND MECHANICAL PROPERTIES OF SOME PLASTICS PACKAGING MATERIALS \\ Gomaa, R.B.A. ${ }^{1}$; F.R.H. Hassan ${ }^{1}$ and I.F. Said-Ahmed ${ }^{2}$ \\ 1- Food Technol. Res. Inst., Agric. Res. Center, Giza, Egypt. \\ 2- Agric. Eng. Res. Inst., Agric. Res. Center, Giza, Egypt. \\ ABSTRACT
}

The effect of gamma radiation on four packaging films [polypropylene (pp), low-density polyethylene (LDPE), polyamide/polyethylene (PA/PE) and polyester/polyethylene (PET/PE)] at levels of 5, 10 and $30 \mathrm{kGy}$ were studied. The effect was included mechanical properties, gas and water vapour permeability and overall migration components from plastic packaging materials into distilled water, $3 \%$ aqueous acetic acid and iso-octane was studied. The results showed that, there were significant differences ( $p>0.05$ ) between mechanical properties of non-irradiated and the samples which were irradiated at levels 5, 10 and $30 \mathrm{kGy}$ for all studied polymers. Irradiation at $30 \mathrm{kGy}$ decreased the impact strenght and percent elongation. The most affected of mechanical property by irradiation at $30 \mathrm{kGy}$ was percent elongation. Irradiation decreased the overall migration from PA/PE and PET/PE into distilled water and $3 \%$ acetic acid. While, the overall migration from PP and LDPE, as well as the overall migration from all the tested packaging materials into iso-octane were increased. The results indicated that overall migration values from all the tested films into distilled water, $3 \%$ acetic acid and iso-octane were lower than the upper limit for migration $\left(10 \mathrm{mg} / \mathrm{dm}^{2}\right)$ set by the EU.

\section{INTRODUCTION}

Chemical and physical properties of plastic packaging materials were changed under irradiation conditions. These types of changes depend on the type of plastic materials, additives used, radiation dose and the other conditions of irradiation (Krupa and Luyt, 2001). Irradiation of packaging materials cause increases in cross-linking and degradation of the polymer structure (Jeon et al., 2004 and Park et al., 2006). This degradation lead to a deterioration of mechanical properties and produce new volatile compounds in certain polymers (Kawamura, 2002). Irradiation not only significantly affect water vapor and carbon dioxide permeability of most plastic polymers,but also affectd oxygen permeability in most polymers (Deschenes et al., 1995).

Polypropylene (PP) is a preferred plastic type for manufacture of a wide variety of multi-layer films, which in turn is being used as retort table flexible food packaging materials, because of its thermal stability. PP is one of the most sensitive polymer to irradiation and at higher irradiation dosage, these films were extremely affected. Most of the literature available data of the effect of irradiation on packaging materials is limited to commonly used monolayer materials like polyethylene (PE), PP, polystyrene, etc., and multilayer materials (Goulas et al., 2003 and Goulas et al., 2004).

Multilayer flexible packaging materials are a significant development of modern packaging technology. Their use finds ever-increasing applications in food, pharmaceutical, medicinal, cosmetics and electronics packaging. Such materials combine a number of desirable properties (barrier to gases and water vapour, mechanical strength, machinability and relatively low cost). Most multilayer structures are based on polyolefins [polyethylene, (PE) and 
polypropylene, (PP)]. Polyolefins have a low cost, are versatile and easy to process. Low-density polyethylene (LDPE) and linear low-density polyethylene (LLDPE) are valued for their toughness and sealability properties. When oxygen, aroma, or flavour protection is necessary, high barrier materials such as ethylene vinyl alcohol (EVOH), polyvinylidene chloride (PVDC) or aluminium applied through vacuum coating processes are used (Twede and Goddard, 1998 and Defosse, 1999).

lonizing radiation effects on polymers have also been widely investigated. They consist mainly of free radicals production. Such free radicals can in turn lead to degradation and or cross linking phenomena (release of gases, discoloration, changes in mechanical properties and gas permeability, degradation and leaching of polymer additives into solvents, etc.),to extent depends on many factors, such as the chemical structure and morphology of the polymer, specific additives used to compound the plastic, the sample's thickness, irradiation dose and dose rate, the irradiation atmosphere, etc. (Brody and Marsh, 1997; Dole, 1972; Killoran, 1972; Buchalla et al., 1993a; Buchalla et al., 1993b.; Buchalla and Boess 1999; Goldman et al., 1996; Deschenes et al., 1995; Goulas et al., 1995; Goulas and Kontominas 1996; Goulas et al., 1998; Goulas et al., 2002 and Riganakos et al., 1999).

Semirigid plastics packaging materials (monolayer or multilayer) find a wide variety of applications in the food, pharmaceutical and cosmetic industry. Also, a variety of moulded plastics products are used for medical applications. Most of these plastic types are sterilized using ionizing radiation before use (Brody and Marsh, 1997). The most commonly radiation dose used for pharmaceutical packaging and medical devices commercial sterilization is the dose of $25 \mathrm{kGy}$, while some countries apply doses between 32-50 kGy. (Klemchik, 1993 and Goldman et al., 1996).

In food preservation by irradiation, foods are usually prepackaged and then irradiated to avoid microbial recontamination. Radiation doses of 20-45 kGy are usually required to obtain commercial sterilization of foods, while absorbed doses of 2-10 kGy are usually required to obtain food pasteurization (WHO, 1988; Diehl, 1992; Goulas et al., 2002 and Goulas et al., 2003).

In the case of irradiation, the presence of air oxygen reacts with the free radicals produced by irradiation and the peroxide radicals formed can then undergo futher reactions leading to chain scission, formation of hydroperoxides, carbonyl groups, acids, discoloration, cross linking, etc.. These reactions depend on the dose and dose rate, oxygen pressure, temperature, polymer chemical structure, morphology, degree of crystallinity, thickness of polymer.The result is the production of low molecular weight (volatile or non-volatile) radiolysis products (Dole, 1991; Burg and Shalaby, 1996; Goldman et al., 1996; Buchalla et al., 1997; Riganakos et al., 1999; Kashiwabara et al., 1991 and Jahan et al,. 2001) The most significance is the correlation between the oxidative degradation process and the properties of irradiated packaging material, especially mechanical strength and migration characteristics after contact with foods, food simulants, pharmaceuticals, etc. 
Goulas et al., (1995); Goulas et al., (1998) and Goulas and Kontominas, (1996), studied the effect of gamma and electron beam radiation on the migration of plasticizers from food-grade polyvinyl chloride (PVC) and (PVDC) films into foods and food simulants.

Goulas et al., (2002) and Goulas et al., (2003), studied the effect of gamma radiation on the physicochemical and mechanical properties (overall migration, gas permeability, tensile strength, percent elongation at break, Young's modulus) of a series of commercial monolayer and multilayer packaging films.

The objective of this work was to:

(1) Study the effect of gamma radiation on the physicochemical and mechanical properties of monolayer (PP, PE) and multilayer (PA/PE, PET/PE) plastics packaging materials.

(2) Determine the overall migration components from plastics packaging materials into three food simulants (distilled water, $3 \%$ aqueous acetic acid, iso-octane)

\section{MATERIALS AND METHODS}

\section{Packaging materials:}

Four packaging films supplied by various industrial companies are listed in Table (1) Polypropylene (pp) film was obtained from the Islamic Company for packages in $6^{\text {th }}$ October city, Giza, Egypt. Whereas, low-density polyethylene (LDPE), polyamide/polyethylene (PA/PE) and polyester/polyethylene (PET/PE)] were obtained from Arabic medical packaging company (flexpack) Cairo, Egypt.

Table (1): Characteristics of the tested packaging materials

\begin{tabular}{|l|c|c|c|c|}
\hline $\begin{array}{c}\text { Packaging } \\
\text { materials }\end{array}$ & $\begin{array}{c}\text { Thickness } \\
(\boldsymbol{\mu} \mathbf{m})\end{array}$ & $\begin{array}{c}\text { Weight per meter } \\
\text { square } \mathbf{( g / \mathbf { m } ^ { 2 } )}\end{array}$ & Printability & $\begin{array}{c}\text { Heat sealing } \\
\text { tem. }(\mathbf{(} \mathbf{C})\end{array}$ \\
\hline P.P & 60 & 10,31 & Poor & 130 \\
\hline LDPE & 55 & 8.96 & Poor & 130 \\
\hline PA/PE & 95 & 16.15 & Medium & 140 \\
\hline PET/PE & 90 & 15.35 & medium & 140 \\
\hline
\end{tabular}

\section{Food simulants :}

Simulants which used in this study were distilled water, acetic acid $3 \%$ and Iso-octane. According to EU Directive 97/48/EEC (EEC, 1997), distilled water and $3 \%$ aqueous acetic acid were used as aqueous and acidic food simulants, respectively. Iso-octane was used as alternative fatty food simulant (EEC, 1997).

Irradiation

The packaging materials were irradiated with Cobalt- 60 source by the use of $\mathrm{Co}^{60}$. The gamma irradiation treatments were done in the National Center for Radiation Research and Technology, Nasr City, Cairo, Egypt. Gamma rays were emitted from unite model Noratom - Nor, and the average dose rates were $0.8 \mathrm{kGy} / \mathrm{h}$ ( radiation doses of 5 and $10 \mathrm{kGy}$ ) and $1.6 \mathrm{kGy} / \mathrm{h}$ (radiation doses of $30 \mathrm{kGy}$ ). 


\section{Mechanical properties tests: Elongation:}

Elongation of the packaging materials, the stretch in a film that will still return to its original size as percentage of original length. Several instruments such as test metric Micro350 or instron may be utilized. Sample strips were cut exactly 1 in wide and about 10 in long. They were gripped at each and by a clamp and then the jaws were moved apart a controlled speed according to the ASTM official method ASTM D 828 (ASTM ,1988).

Impact strength :

Impact strength $\left(\mathrm{N} / \mathrm{cm}^{2}\right)$ of the package material is the difference between the energy of a puncture pendulum, which was allowed to swing through a sample, at maximum height and the energy of the pendulum after the sample was ruptured. The test metric Micro 350 was used.

\section{Gas permeability determination:}

Permeability values to water vapour was determined using the standard test method (ASTM) described by Ranganna (1977). While, Permeability values to carbon dioxide and oxygen were determined using GLC system. The measure until used was $\left(\mathrm{cm}^{3} \cdot \mathrm{m}\right.$. day) according to the method described by Eustace, (1981)

\section{Determination of overall migration from packaging materials into food} simulants:

Overall migration into aqueous food simulants (distilled water, $3 \%$ acetic acid) and alternative fatty food simulant (iso-octane) was estimated according to the method described by De Kruijf and Rijk, (1995). The total migration was measured by filling a simple migration cell with a suitable amount of food simulant $(200 \mathrm{~mL})$, while the test pieces were cut to provide contact surface of $10 \times 10 \mathrm{~cm}\left(1 \mathrm{dm}^{2}\right)$ for all the packaging materials used in this study (LDPE, PP, PA/PE and PET/PE). Each type of plastic were immersed in the food simulants. The samples were stored under the appropriate test conditions at $40 \pm 0.5^{\circ} \mathrm{C}$ for, 10 days for distilled water, $3 \%$ acetic acid and $20 \pm 0.5^{\circ} \mathrm{C}$ for 2 days for iso-octane (EEC 1997). After the storage period, the simulant was filtered through a $\mathrm{G}_{3}$ glass filter into a 500 $\mathrm{mL}$ conical flask. The sample and the filter were washed with about $25 \mathrm{~mL}$ of simulant. The washing were added to the same conical flask. The simulant was evaporated using a hot-plate, to a volume of Ca. $25 \mathrm{~mL}$. The resulting solution was transferred to a $100 \mathrm{~mL}$ conical flask which has been dried for $1 \mathrm{~h}$ at $105^{\circ} \mathrm{C}$ and previously weighted $\left(\mathrm{G}_{\mathrm{v}}\right)$. The solvent was evaporated to dryness. The residue was dried for $1 \mathrm{~h}$ at $105^{\circ} \mathrm{C}$ in an oven and weighted after cooling to room temperature at a desiccator $\left(G_{n}\right)$. The concentration of the total migrated components $\left(G_{M}\right)$ is determined according to the following equation: $G_{M}=G_{n}-G_{v}$

\section{RESULTS AND DISCUSSION}

Effect of irradiation on some plastics materials:

1- Effect of irradiation on mechanical properties of the packaging materials:

Mechanical properties data of non-irradiated (control) and irradiated packaging materials are given in Table (2). For all polymers, there were 
significant differences $(p>0.05)$ in mechanical properties of non-irradiated and irradiated samples at 5,10 and $30 \mathrm{kGy}$. Irradiation at $30 \mathrm{kGy}$ resulted in a decrease in impact strength of the PP, LDPE, PA/PE and PET/PE films by $17.3,13.66,4.3$ and $14.15 \%$ respectively. The same dose resulted in a decrease of percent elongation of the PP, LDPE, PA/PE and PET/PE films by $50.57,36.63,30.07$ and $44.89 \%$ respectively. The mechanical property most affected by irradiation at $30 \mathrm{kGy}$ was percent elongation. These results are in agreement with data of Wilski (1987), who reported that the elongation is the most radiation-sensitive property.

Table (2): Effect of irradiation on mechanical properties of tested packaging materials

\begin{tabular}{|c|c|c|c|}
\hline $\begin{array}{c}\text { Packaging } \\
\text { materials }\end{array}$ & $\begin{array}{c}\text { Radiation dose } \\
\text { (KGy) }\end{array}$ & $\begin{array}{c}\text { Impact strenght } \\
\left(\mathbf{N} / \mathbf{c m}^{\mathbf{2}} \text { ) }\right.\end{array}$ & $\begin{array}{c}\text { Percent } \\
\text { elongation }\end{array}$ \\
\hline & 0 & $11980 \mathrm{a}$ & $87 \mathrm{a}$ \\
& 5 & $10800 \mathrm{~b}$ & $66 \mathrm{~b}$ \\
& 10 & $10806 \mathrm{~b}$ & $61 \mathrm{c}$ \\
& 30 & $9940 \mathrm{c}$ & $43 \mathrm{~d}$ \\
\hline & 0 & $3220 \mathrm{a}$ & $101 \mathrm{a}$ \\
LDPE & 5 & $3192 \mathrm{~b}$ & $56 \mathrm{c}$ \\
& 10 & $3198 \mathrm{~b}$ & $61 \mathrm{~b}$ \\
& 30 & $2780 \mathrm{c}$ & $64 \mathrm{~b}$ \\
\hline & 0 & $1650 \mathrm{c}$ & $266 \mathrm{~b}$ \\
PA/PE & 5 & $1792 \mathrm{a}$ & $288 \mathrm{a}$ \\
& 10 & $1684 \mathrm{~b}$ & $261 \mathrm{c}$ \\
\hline & 30 & $1580 \mathrm{~d}$ & $186 \mathrm{~d}$ \\
\hline & 0 & $2155 \mathrm{c}$ & $147 \mathrm{~b}$ \\
PET/PE & 5 & $2196 \mathrm{a}$ & $180 \mathrm{a}$ \\
& 10 & $2170 \mathrm{~b}$ & $134 \mathrm{c}$ \\
\hline
\end{tabular}

All values are means of three determinations.

The most stable polymer of all samples examined was PA/PE. This can be explained by the structure of PA/PE. While, the most effect in mechanical properties at a dose of $30 \mathrm{kGy}$ was observed with PP film as indicated by a more than $50 \%$ decrease in elongation at break after 30 kGy. The other examined materials showed moderate to severe degradation at $30 \mathrm{kGy}$. This is in agreement with data of Bourges et al., (1992) and Feigenbaum et al., (1995). They found that, the most effect in mechanical properties at a dose of $30 \mathrm{kGy}$ was observed for PP film which became extremely brittle. Polymer degradation increases in the presence of air because oxygen is extremely reactive with the free radicals produced by irradiation. Overall, the mechanical properties of irradiated examined films were largely different from those of the non-irradiated films. Deterioration of mechanical properties can be attributed to the radiation which induced degradation of the polymers. Degradation is expressed as formation of free radicals, production of low molecular weight volatile or non-volatile radiolysis products, production of hydrogen and subsequent increase of unsaturated bonds, polymer chain scission, molecular weight decrease, etc.(Dole, 1972 Buchalla et al., 1993a and Brody et al., 1997). 
Gomaa, R.B.A. et al.

Goldman et al., (1996) and Fengmei et al., (2000) studied effects of gamma radiation doses (5, 10 and $25 \mathrm{kGy}$ ) on mechanical properties of Nylon/polyvinylidene, chloride/polyethylene and observed that, there was no significant difference in tensile strength and percent elongation after irradiation at a dose of $5 \mathrm{kGy}$; while irradiation doses of 10 and $25 \mathrm{kGy}$ slightly lowered the above mechanical properties. Differences observed among various findings may be related to chemical structure of individual layers, thickness of samples, irradiation dose rate as well as environmental parameters (temperature, relative humidity, etc).

\section{2- Effect of irradiation on Gas permeability:}

Water vapour ,carbon dioxide and oxygen permeability values of nonirradiated (control) and irradiated (5, 10 and $30 \mathrm{kGy}$ ) packaging materials are given in Table (3). As shown in this table there were no significant differences in permeability values after irradiation at a dose of $5 \mathrm{kGy}$; while irradiation doses of 10 and $30 \mathrm{kGy}$ showed significant difference in the permeability values.

Polypropylene films showed very low permeability water vapour values $\left(1.3-1.6 \mathrm{~g} / \mathrm{m}^{2} \mathrm{~d}\right)$ compared to other films, suggesting that these materials are suitable and could be used extensively for foods that demands high barrier protection. While, PA/PE films showed high permeability water vapour values $\left(2.6-3.1 \mathrm{~g} / \mathrm{m}^{2} \mathrm{~d}\right)$ compared to other films. Irradiation at $30 \mathrm{kGy}$ increased water vapour permeability values for PP (from 1.4 to $1.6 \mathrm{~g} / \mathrm{m}^{2} \mathrm{~d}$ ) and LDPE (from 2.8 to $3.1 \mathrm{~g} / \mathrm{m}^{2} \mathrm{~d}$ ). While, it decreased water vapor permeability values for PA/PE from 3.1 to $2.6 \mathrm{~g} / \mathrm{m}^{2} \mathrm{~d}$ and for PET/PE from 2.0 to $1.6 \mathrm{~g} / \mathrm{m}^{2} \mathrm{~d}$.

Table (3): Effect of irradiation on permeability values of tested packaging materials

\begin{tabular}{|c|c|c|c|c|}
\hline $\begin{array}{c}\text { Packaging } \\
\text { materials }\end{array}$ & $\begin{array}{c}\text { Radiation } \\
\text { dose } \\
\text { (KGy) }\end{array}$ & $\begin{array}{l}\text { Water vapor } \\
\left(\mathrm{g} / \mathrm{m}^{2} \mathrm{~d}\right)\end{array}$ & $\begin{array}{c}\text { Carbon } \\
\text { dioxide } \\
\text { Permeability } \\
\left(\mathrm{CC} / \mathrm{m}^{2} \mathrm{~d}\right)\end{array}$ & $\begin{array}{c}\text { Oxygen } \\
\text { Permeability } \\
\left(\mathrm{CC} / \mathrm{m}^{2} \mathrm{~d}\right)\end{array}$ \\
\hline \multirow{4}{*}{ P.P } & 0 & $1.40 \mathrm{~b}$ & $2216 \mathrm{~b}$ & $958 \mathrm{~b}$ \\
\hline & 5 & $1.30 \mathrm{~b}$ & $2220 \mathrm{~b}$ & $959 \mathrm{~b}$ \\
\hline & 10 & $1.40 \mathrm{~b}$ & $2218 b$ & $961 \mathrm{~b}$ \\
\hline & 30 & $1.60 \mathrm{a}$ & $2228 \mathrm{a}$ & $966 \mathrm{a}$ \\
\hline \multirow{4}{*}{ LDPE } & 0 & $2.80 \mathrm{~b}$ & $4088 \mathrm{~b}$ & $2125 \mathrm{bc}$ \\
\hline & 5 & $2.70 \mathrm{~b}$ & $4087 \mathrm{~b}$ & $2124 \mathrm{c}$ \\
\hline & 10 & $2.70 \mathrm{~b}$ & $4090 \mathrm{~b}$ & $2128 a b$ \\
\hline & 30 & $3.10 \mathrm{a}$ & $4098 a$ & $2132 \mathrm{a}$ \\
\hline \multirow{4}{*}{ PA/PE } & 0 & $3.10 \mathrm{a}$ & $86.0 \mathrm{a}$ & $26.00 \mathrm{a}$ \\
\hline & 5 & $3.00 \mathrm{a}$ & $860 \mathrm{a}$ & $26.10 \mathrm{a}$ \\
\hline & 10 & $2.82 \mathrm{~b}$ & $85.70 \mathrm{a}$ & $26.30 \mathrm{a}$ \\
\hline & 30 & $2.60 \mathrm{c}$ & $85.90 \mathrm{a}$ & $26.0 \mathrm{a}$ \\
\hline \multirow{4}{*}{ PET/PE } & 0 & $2.00 \mathrm{a}$ & $464 \mathrm{a}$ & $102.0 \mathrm{a}$ \\
\hline & 5 & $2.10 \mathrm{a}$ & $460 \mathrm{a}$ & $102.0 \mathrm{a}$ \\
\hline & 10 & $1.80 \mathrm{~b}$ & $463 \mathrm{a}$ & $103.5 \mathrm{a}$ \\
\hline & 30 & $1.60 \mathrm{c}$ & $465 a$ & $104.0 \mathrm{a}$ \\
\hline
\end{tabular}


From the same data illustrated in the Table (3), it can be observed that LDPE films showed the greatest permeability values compared to other films which increased from 4088 to 4098 and 2125 to $2132 \mathrm{cc} / \mathrm{m}^{2} \mathrm{~d}$ for carbon dioxide and oxygen permeability, respectively. While, PA/PE films recorded the lowest permeability values compared to other films which non-signficantly decreased from 86 to 85.7 and increesed from 26 to $26.3 \mathrm{CC} / \mathrm{m}^{2} \mathrm{~d}$ for carbon dioxide and oxygen permeability, respectively. Oxygen permeability increase with increasing radiation dose. The result, also showed that the permeability of both carbon dioxide and oxygen using the packaging materials of PP, LDPE, PET/PE was increased from 2216, 4088, 464 to 2228, 4098, 465 $\mathrm{CC} \mathrm{m}^{2}$ day for carbon dioxide and from 958, 2125, 102 to 966, 2132, 104 $\mathrm{CC} \mathrm{m}^{2}$ day for oxygen permeability.

Riganakos et al., (1999) studied the effect of high dose electron beam radiation ( $100 \mathrm{kGy}$ ) on the oxygen, carbon dioxide and water vapour permeability of $\mathrm{PET} / \mathrm{PE} / \mathrm{EVOH} / \mathrm{PE}$ (laminated/coextruded) multilayer structure and observed no significant differences in permeability values. Deschenes et al., (1995) studied the effect of gamma and electron beam radiation (0$25 \mathrm{kGy}$ ) on oxygen, carbon dioxide and water vapour permeability of a Nylon/polyvinylidene chloride/EVA copolymer film and reported that the permeability of water vapour and carbon dioxide was not significantly affected by the irradiation doses investigated. However, oxygen permeability increased with absorbed dose. Kim-Kang and Gilbert (1991) reported that gamma radiation doses of 27-32 kGy induced no change in water vapour permeability of $\mathrm{PE} /$ polyvinylidene chloride/Glycol modified polyethylene terephtalate (PETG) but significantly reduced its oxygen permeability.

3- Effect of irradiation on overall migration into aqueous simulants and iso-octane

a) Effect of irradiation on overall migration into aqueous simulants

Overall migration data from non-irradiated (control) and irradiated tested packaging materials into aqueous food simulants (distilled water and $3 \%$ aqueous acetic acid) are given in Table (4) and Table (5) respectively.

Table (4): Overall migration values $\left(\mathrm{mg} / \mathrm{dm}^{2}\right)$ into distilled water from the tested packaging materials

\begin{tabular}{|l|c|c|c|c|}
\hline \multirow{2}{*}{$\begin{array}{c}\text { Packaging } \\
\text { materials }\end{array}$} & $\mathbf{4}$ & $\mathbf{5}$ & $\mathbf{1 0}$ & $\mathbf{3 0}$ \\
\cline { 2 - 5 } & $\mathbf{0}$ & $1.00 \mathrm{ab}$ & $0.90 \mathrm{~b}$ & $1.10 \mathrm{a}$ \\
\hline $\mathrm{P} . \mathrm{P}$ & $1.20 \mathrm{ab}$ & $1.10 \mathrm{~b}$ & $1.10 \mathrm{~b}$ & $1.30 \mathrm{a}$ \\
\hline $\mathrm{LDPE}$ & $0.70 \mathrm{a}$ & $0.60 \mathrm{ab}$ & $0.60 \mathrm{ab}$ & $0.50 \mathrm{~b}$ \\
\hline $\mathrm{PA} / \mathrm{PE}$ & $0.55 \mathrm{a}$ & $0.50 \mathrm{a}$ & $0.50 \mathrm{a}$ & $0.35 \mathrm{~b}$ \\
\hline $\mathrm{PET} / \mathrm{PE}$ & &
\end{tabular}

All values are means of three determinations.

For distilled water (Table 2), the lower doses of 5 and $10 \mathrm{kGy}$ caused no clear significant differences in overall migration between irradiation and control samples; while irradiation doses at $30 \mathrm{kGy}$ showed a significant difference in overall migration with PA/PE and PET/PE. Overall migration from all tested packaging materials into distilled water was ranged between 
0.5 and $1.3 \mathrm{mg} / \mathrm{dm}^{2}$. The greatest Overall migration with LDPE films compared to other tested packaging materials $\left(1.10-1.30 \mathrm{mg} / \mathrm{dm}^{2}\right)$. While, the lowest Overall migration with PET/PE films compared to other tested films $\left(0.35-0.55 \mathrm{mg} / \mathrm{dm}^{2}\right)$. The obtained levels of overall migration were lower than the upper limit $\left(10 \mathrm{mg} / \mathrm{dm}^{2}\right)$ for food approved plastics packaging materials $(E C C, 1990)$.

Table (5): Overall migration values $\left(\mathrm{mg} / \mathrm{dm}^{2}\right)$ into $3 \%$ acetic acid from the tested packaging materials

\begin{tabular}{|l|c|c|c|c|}
\hline \multirow{2}{*}{$\begin{array}{c}\text { Packaging } \\
\text { materials }\end{array}$} & \multicolumn{4}{|c|}{ Radiation dosage (Kgy) } \\
\cline { 2 - 5 } & $\mathbf{0}$ & $\mathbf{5}$ & $\mathbf{1 0}$ & $\mathbf{3 0}$ \\
\hline $\mathrm{P} . \mathrm{P}$ & $2.40 \mathrm{c}$ & $2.20 \mathrm{~d}$ & $2.70 \mathrm{~b}$ & $3.30 \mathrm{a}$ \\
\hline $\mathrm{LDPE}$ & $1.20 \mathrm{~b}$ & $1.20 \mathrm{~b}$ & $1.40 \mathrm{a}$ & $1.30 \mathrm{ab}$ \\
\hline $\mathrm{PA} / \mathrm{PE}$ & $0.60 \mathrm{a}$ & $0.50 \mathrm{a}$ & $0.60 \mathrm{a}$ & $0.60 \mathrm{a}$ \\
\hline $\mathrm{PET} / \mathrm{PE}$ & $0.60 \mathrm{a}$ & $0.55 \mathrm{a}$ & $0.60 \mathrm{a}$ & $0.60 \mathrm{a}$ \\
\hline
\end{tabular}

All values are means of three determinations.

For $3 \%$ acetic acid, there were no significant differences in overall migration between irradiated and control samples with PA/PE and PET/PE. While, significant differences were observed in overall migration with PP and LDPE. Overall migration from all tested packaging materials into $3 \%$ acetic acid was $\left(0.5-3.3 \mathrm{mg} / \mathrm{dm}^{2}\right)$. These levels are well below of the current European Union upper limit of $10 \mathrm{mg} / \mathrm{dm}^{2}$ for food approved plastics packaging materials (EEC, 1990). Overall migration from PP was higher than other tested packaging materials. While, Overall migration from PA/PE was less than other tested packaging materials. Killoran, (1972) studied effects of gamma radiation doses (60 - $67 \mathrm{kGy})$ on migration values of polyethylenepolyisobutylene blend into water and acetic acid and reported that, no significant differences in migration values between irradiated and control samples. Buchalla, et al., (1993 b) reported that $60 \mathrm{kGy}$ of gamma radiation caused no significant change in the extractability of 10 laminates, six of which having PE as inner layer and the rest four having PVC, PA-11, polyester and polycarbonate as the inner layer, respectively. Kim-Kang and Gilbert (1991) reported that radiation doses of 27-32 kGy resulted in a decrease in the extractable from a PE/PVDC/PETG multilayer structure into water.

\section{b) Effect of irradiation on overall migration into iso-octane}

Overall migration values from control and irradiated packaging materials into iso-octane are presented in Table (6). The results indicate that the lower radiation doses at 5 and $10 \mathrm{kGy}$ caused no significant differences $(p>0.05)$ in overall migration into iso-octane. At $30 \mathrm{kGy}$ there was an increase (17.74, 8.69 and $42.85 \%$ ) in overall migration from PP, LDPE and PA/PE films, respectively. Migration values into iso-octane are higher than migration values into $3 \%$ aqueous acetic acid and also higher than migration values into distilled water. This can be explained by the capability of iso-octane to penetrate into the plastic packaging materials, causing swelling of the polymer and thus change in its structure. 
The results in Table (6) also show that the overall migration values from all samples are lower than the upper migration limit set by the European Union (EEC, 1997). There is very little information in the literature on effects of radiation on migration from packaging materials into fatty food simulants. Kim-Kang and Gilbert (1991) reported that radiation doses of 27-32 kGy caused no change in extractable from PE/PVDC/PETG into $n$-heptane. Killoran (1972) found a high increase in migration from a polyethylenepolyisobutylene blend into $n$-heptane after gamma irradiation with $60 \mathrm{kGy}$.

Table (6): Overall migration values $\left(\mathrm{mg} / \mathrm{dm}^{2}\right)$ into iso-octane from the tested packaging materials

\begin{tabular}{|l|c|c|c|c|}
\hline \multirow{2}{*}{$\begin{array}{c}\text { Packaging } \\
\text { materials }\end{array}$} & \multicolumn{4}{|c|}{ Radiation dosage (Kgy) } \\
\cline { 2 - 5 } & $\mathbf{0}$ & $\mathbf{5}$ & $\mathbf{1 0}$ & $\mathbf{3 0}$ \\
\hline P.P & $6.20 \mathrm{bc}$ & $6.00 \mathrm{c}$ & $6.40 \mathrm{~b}$ & $7.30 \mathrm{a}$ \\
\hline $\mathrm{LDPE}$ & $2.30 \mathrm{~b}$ & $2.20 \mathrm{~b}$ & $2.60 \mathrm{a}$ & $2.50 \mathrm{a}$ \\
\hline $\mathrm{PA} / \mathrm{PE}$ & $1.40 \mathrm{bc}$ & $1.20 \mathrm{c}$ & $1.60 \mathrm{~b}$ & $2.00 \mathrm{a}$ \\
\hline $\mathrm{PET} / \mathrm{PE}$ & $0.70 \mathrm{a}$ & $0.60 \mathrm{a}$ & $0.60 \mathrm{a}$ & $0.70 \mathrm{a}$ \\
\hline
\end{tabular}

\section{CONCLUSION}

The results showed that radiation doses of 5 and $10 \mathrm{kGy}$ had no significant differences $(p>0.05)$ in mechanical properties, permeability and overall migration of tested packaging materials. The dose of $30 \mathrm{kGy}$ caused to decrease $(p<0.05)$ in the mechanical properties for all polymers. Also, irradiation induced a decrease $(p<0.05)$ in the overall migration from PA/PE and PET/PE into distilled water and $3 \%$ acetic acid and an increase in the overall migration from PP and LDPE.

Irradiation induced an increase in the overall migration from all tested packaging materials into iso-octane. The overall migration values from all tested films into distilled water, $3 \%$ acetic acid and iso-octane were lower than the upper limit for migration $\left(10 \mathrm{mg} / \mathrm{dm}^{2}\right)$ set by the EU.

\section{REFERENCES}

ASTM (1988). Standard specification for polyethylene plastics molding and extrusion materials D 1248-84, Annual Book of ASTM standard, American Society for Testing and Materials, Philadelphia 8: 423.

Bourges, F., Bureau, G., Dumonceau, J. and Pascat, B.(1992). Effects of electron beam irradiation on antioxidants in commercial polyolefins: determination and quantification of products formed. Packag. Technol. Sci. 5, pp. 205-209.

Brody, A.L. and Marsh, K.S. (1997). The Wiley Encyclopedia of Packaging Technology, 2nd Edition. Wiley, New York.

Buchalla, R.; Schuttler, C. and Bogl K.W. (1993a). Effect of ionizing radiation on plastic food packaging materials: a review. Part 1 . Chemical and physical changes. J. Food Prot. 56: 991-997. 
Buchalla, R.; Schuttler, C. and Bogl K.W. (1993b) Effect of ionizing radiation on plastic food packaging materials: a review. Part 2. Global migration, sensory changes and the fate of additives. J. Food Prot. 56: 998-1005.

Buchalla, R. and Boess, C. (1999). Characterization of volatile radiolysis products in radiation-sterilized plastics by thermal desorption-gas chromatography-mass spectrometry: screening of six medical polymers. Radiat. Phys. Chem. 56: 353-367.

Buchalla, R. and Boess, C. and Bogl, K.W. (1997). Radiolysis Products in Gamma-irradiated-plastics by Thermal Desorption-GC-MS. Part 1. Federal Institute for Health Protection of Consumers and Veterinary Medicine (BgVV), Berlin, Germany.

De Kruijf, N. and Rijk, M.A.H. (1995). Applicability of volatile stimulants for routine overall migration testing. Conference Packaging materials in contact with foodstuffs, London, UK.

Defosse, M.T. (1999) Blow molded packaging melds style and substance. Modern Plast. Int. 47-50.

Deschenes, L. Arbour, A. Brunet, F. Court, M.A. Doyon, G.J. Fortin J. and Rodrigue, N. (1995). Irradiation of a barrier film: analysis of some mass transfer aspects. Radiat. Phys. Chem. 46: $805-808$.

Diehl, J.F. (1992) Food irradiation: is it an alternative to chemical preservatives?. Food Addit. Contam. 9: 409 - 416

Dole, M. (1972). The Radiation Chemistry of Macromolecules, Vol. I and II. Academic Press, New York.

Dole, M.(1991) The radiation chemistry of polymer composites. Radiat. Phys. Chem. 37: 65-70.

EEC (1990). Commission Directive 90/128/EEC of 23 February 1990, relating to plastic materials and articles intended to come into contact with foodstuffs. Off. J. Eur. Commun. L 75, Brussels, 19-39.

EEC (1997). Commission Directive No. 97/48/EC. Official Journal of the European Communities No. L. 222, 12.08, pp 10-15.

Eustace, I.J. (1981). Some factors affecting oxygen transmission rates of plastic films for vacuum packaging of meat. J. F.D. Tech. 16: 73-80.

Feigenbaum, A., Marque, D. and Riquet, A.-M.(1995). Compatibility of plastic materials with foodstuffs: mechanistic and safety aspects of ionized polypropylene. In: Food and Packaging Materials-chemical Interactions, Royal Society of Chemistry, UK, pp. 87-94.

Fengmei,L; Ying, W.; Xiaoguang, L and Baoyu, Y. (2000). Evaluation of plastic packaging materials used in radiation sterilized medical products and food.Radiat. Phys. Chem. 57 (2000), pp. 435-439

Goldman, M.; Gronsky, R.; Ranganathan, R.; and Pruitt, L. (1996). The effects of gamma radiation sterilization and ageing on the structure and morphology of medical grade ultra high molecular weight polyethylene. Polymer 37: 2909-2913.

Goulas, A.E. and Kontominas, M.G. (1996). Migration of dioctyladipate plasticizer from food-grade PVC film into chicken meat products effect of y-radiation. Z. Lebensm. Unters. Forsch. 202, pp. 250-255. 
Goulas, A.E. Kokkinos, A. and Kontominas, M.G. (1995). Effect of Y-radiation on migration behaviour of dioctyladipate and acetyltributylcitrate plasticizers from food-grade PVC and PVDC/PVC films into olive oil. Z. Lebensm. Unters. Forsch. 201: 74-78.

Goulas, A.E.; Riganakos, K.A.; Ehlermann, D.A.E.; Demertzis P.G. and Kontominas, M.G. (1998). Effect of high-dose electron beam irradiation on the migration of DOA and ATBC plasticizers from food-grade PVC and PVDC/PVC films, respectively, into olive oil. J. Food Prot. 61: 720724.

Goulas, A.E; Riganakos, K.A.; Badeka, A. and Kontominas, M.G. (2002). Effect of ionizing radiation on the physicochemical and mechanical properties of commercial monolayer flexible plastics packaging materials. Food Addit. Contam. 19: 1190-1199.

Goulas, A.E; Riganakos, K.A. and Kontominas, M.G. (2003). Effect of ionizing radiation on physicochemical and mechanical properties of commercial multilayer coextruded flexible plastics packaging materials. Radiat. Phys. Chem.

Goulas, A.E; Riganakos, K.A. and Kontominas, M.G. (2004). Effect of ionizing radiation on physicochemical and mechanical properties of commercial monolayer and multilayer semi rigid plastics packaging materials, Radiat. Phys. Chem. 69 (5): 411- 417.

Jeon, D.H; Lee, K.H. and Park, H.J. (2004). The effects of irradiation on physicochemical characteristics of PET packaging film, Radiat. Phys. Chem. 71 (5): 1059 - 1064.

Jahan, M.S.; King, M.C.; Haggard, W.O.; Sevo, K.L. and Parr, J.E. (2001). A study of long-lived free radicals in gamma-irradiated medical grade polyethylene. Radiat. Phys. Chem. 62: 141-144

Kawamura, Y. (2002). Effects of gamma irradiation on polyethylene, polypropylene, and polystyrene. In: V. Komoprasert and K.M. Morehouse, Editors, Irradiation of Food and Packaging, American Chemical Society, Washington, DC (2002): 262-276.

Killoran, J.J. (1972). Chemical and physical changes in food packaging materials exposed to ionizing radiation. Radiat. Res. Rev. 3: 369-388.

Kim-Kang,H. and Gilbert, S.G.(1991). Permeation characteristics of and extractables from gamma-irradiated and non-irradiated plastic laminates for a unit dosage injection device. Packag. Technol. Sci. 4 (1991), pp. 35-48.

Klemchik, P.P. (1993). Protecting polymers against damage from gamma radiation. Radiat. Phys. Chem. 41: 165-172.

Kashiwabara, H.; Shimada, S. and Hori, Y. (1991). Free radicals and crosslinking in irradiated polyethylene. Radiat. Phys. Chem. 37: 43 46.

Krupa, I. and Luyt, A.S. (2001). Thermal properties of isotactic propylene degraded with gamma irradiation, Polym. Degrad. Stabil. 72: 505-508.

Park, G.Y.; Cho, S.Y.; Jeon, D.H.; Kwak, I.S.; Lee K.H. and Park, H.J. (2006). Formation of monomer residues in PS, PC, PA-6 and PVC upon $\mathrm{Y}$ irradiation, Radiat. Phys. Chem. 75(9): 1055-1059. 


\section{Gomaa, R.B.A. et al.}

Ranganna, S. (1977). Manual of analysis of fruit and vegetable products. Tata McGraw-Hill Publishing Company Limited, New Delhi.

Riganakos, K.A.; Koller, W.D.; Ehlermann, D.A.E.; Bauer, B. and Kontominas, M.G. (1999). Effects of ionizing radiation on properties of monolayer and multilayer flexible food packaging materials. Radiat. Phys. Chem. 54: 527-540.

Twede, D. and Goddard. R. (1998). Packaging materials (2nd Edition ed.), Pira International, Surrey, UK.

Wilski, H.( 1987). The radiation induced degradation of polymers. Radiat. Phys. Chem. 29, pp. 1-14

WHO. (1988). Food Irradiation. World Health Organization, Geneva.

تأثير أثـعة جامـا على الخصـائص الكيميائيـة والفيزيائيسة والميكانيكيـة لبعض مواد

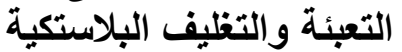

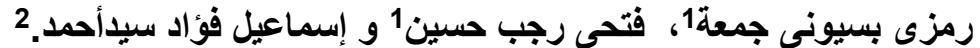

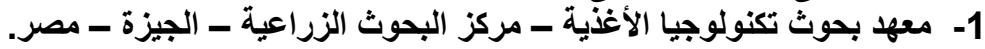
2- 1- معهد بحوث الهندة الزراعية ـ مركز البحوث الزراعية ــ الجيزة ـ مصر.

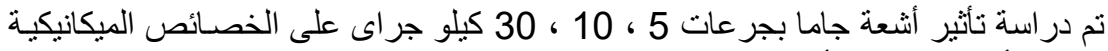

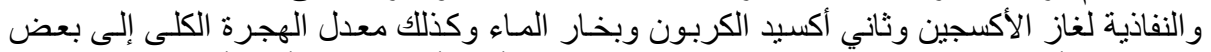

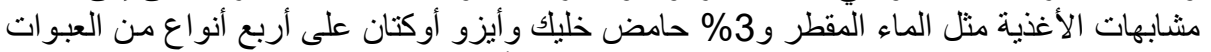

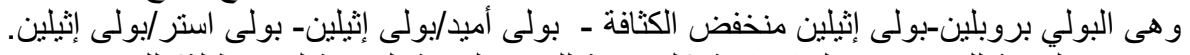

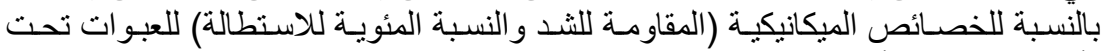

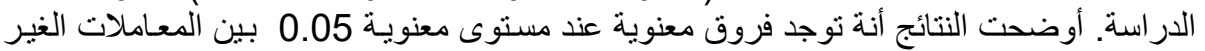

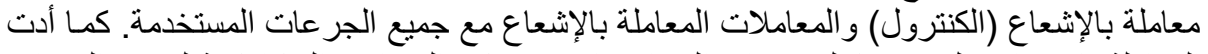

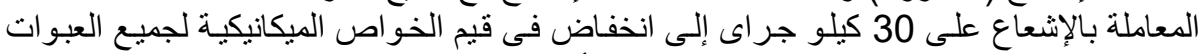
بنسب مختلفة وكانت اكثر الخو اص الميكانيكية تأثرا بالإنشعاع على 30 كيلو جرى هي النسبة النية المئوية للاستطالة.

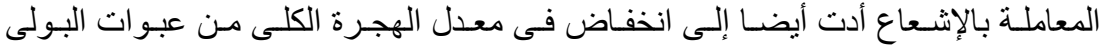

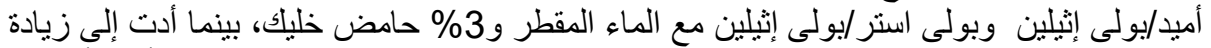

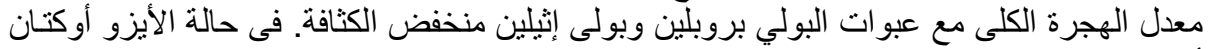

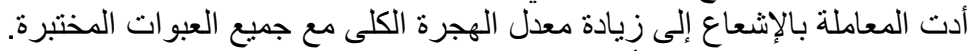

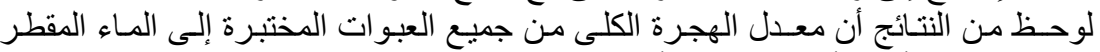

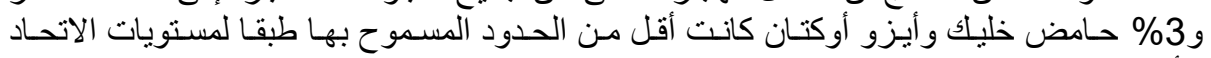
الأوروبى (10 ملجم/ ديسيمتر مربع). 